Relations industrielles

Industrial Relations

\title{
"Progress-Sharing" can mean Industrial Peace (Reader's Digest, September, 1952, Canadian Edition, pages 81 to 85.)
}

\section{Jean-H. Gagné}

Volume 8, numéro 1, décembre 1952

URI : https://id.erudit.org/iderudit/1023025ar

DOI : https://doi.org/10.7202/1023025ar

Aller au sommaire du numéro

Éditeur(s)

Département des relations industrielles de l'Université Laval

ISSN

0034-379X (imprimé)

1703-8138 (numérique)

Découvrir la revue

Citer ce compte rendu

Gagné, J.-H. (1952). Compte rendu de ["Progress-Sharing" can mean Industrial Peace (Reader's Digest, September, 1952, Canadian Edition, pages 81 to 85.)]. Relations industrielles / Industrial Relations, 8(1), 163-163.

https://doi.org/10.7202/1023025ar

Tous droits réservés (C Département des relations industrielles de l’Université Laval, 1952
Ce document est protégé par la loi sur le droit d'auteur. L'utilisation des services d'Érudit (y compris la reproduction) est assujettie à sa politique d'utilisation que vous pouvez consulter en ligne.

https://apropos.erudit.org/fr/usagers/politique-dutilisation/ 
only the sample plans were kept, giving details such as the name of the company, the number of employees concerned, the existence or not of a union, etc. This digest illustrates well that the profit sharing plan can be applied to any kind of business.

The Council of Profit Sharing Industries must be congratulated on publishing this work which will surely interest those businesses who want to get away from beaten paths and find ways to make our economy more human and more democratic.

G. D.

\section{"Progress-Sharing" can mean Industrial Peace.}

An article published in the "Reader's Digest" of September, 1952 and written by Charles E. Wilson, President of General Motors Corp. has particularly attracted our attention.

The Author presents quite briefly but in a very instructive way, the new collective agreement formula agreed upon between the Company of which he is the president, and its employees' union.

This formula has several interesting points, among others, it provides that the contract will run for five years and fixes in advance a method of adjusting and increasing wages during the course of the agreement, all based on scientifically interpreted official statistics.

The Author also makes some interesting comments in regard to the influence of the variation in wages and prices on inflation. These considerations are based on statistics covering a period of thirty years in the economic life of the United States.

He claims that increases in workers' wages do not cause inflation, but try to follow previous increases in prices, which are often caused by political decisions.

J. H. G.

(Reader's Digest, September, 1952,

Canadian Edition, pages 81 to 85 .)

\section{LIVRES REÇUS}

Chamberlain, Neil W., Collective Bargaining, 494 pp., published by McGrawHill Book Company Inc., N.Y., Toronto, London, 1951.

Ginzberg, Eli, The Labor Leader, 190 pp. published by the MacMillan Company, New York, 1948.

Melnyk, Myroslaw, Les ouvtiers étrangers en Belgique, 183 pp., publié par Institut des recherches économiques et sociales de l'Université de Louvain," Place Monseigneur Ladeuze, Louvain 1951.

Ripert, G., Le droit privé francais au milieu du XXe siècle, Pichon et Durand Paris 1950, 2 vol.

Rose, A.M., Union Solidarity, 209 pp., published by the University of Minnesota Press, Minneapolis, U.S.A., LondonGeoffrey Cumberlege, Oxford University Press, 1952.

Toubeau, R., Responsabilités actuelles des chefs d'entreprise, 114 pp., Editions Universitaires, Paris, 1952 .

Industrial Relations Research Association, Interpreting the Labor Movement, Park and University, Temp. 3, Room 5, Madison 5, Wisconsin, December 1952, 207 pages. 